\title{
EFFECT OF SOCIAL EXCLUSION ON CLIMATE CHANGE ADAPTATION OF FEMALE ARABLE CROP FARMERS IN ABIA STATE, NIGERIA
}

\author{
Ifeanyi-obi, C. C. ${ }^{1}$ and Ugorji, E. C. \\ Correspondence authors: C. C. Ifeanyi-obi. Email: clara.ifeanyi-obi@ uniport.edu.ng
}

\begin{abstract}
The need to reduce social exclusion suffered by female arable crop farmers in Abia State as a way of enhancing their climate change adaptive capacity prompted this study. The study identified the effect of social exclusion on climate change adaptation of female arable crop farmers in Abia State, Nigeria. A multiple stage sampling procedure was employed to select 120 respondents for the study. Data were collected with the aid of questionnaires complemented with an interview schedule. Both descriptive and inferential statistics were used to analyse the data. The major effects of social exclusion on the climate change adaptation of female arable crop farmers includes poor access to credit facilities to enhance adaptation activities $(\bar{x}=2.8)$, lack of ownership to land for increased farm size $(\bar{x}=2.8)$, and inadequate access to important agricultural equipment and inputs for better adaptation $(\bar{x}=2.7)$. The ordinary least square regression analysis showed that a significant relationship exists between the socio-economic characteristics of the female arable crop farmers and the level of social exclusion they suffer. It was recommended that formal education of women, skill acquisition and empowerment programmes for women, and enlightenment by extension and advisory services on the implications of social exclusion could aid in the reduction of social exclusion amongst female arable crop farmers.
\end{abstract}

Keywords: Arable crop farmers, Climate change adaptation, Female farmers, Extension

\section{INTRODUCTION}

The issue of climate change has become very topical in Nigeria because of its obvious adverse effects on almost every aspect of the nation's economy. The Intergovernmental Panel on Climate Change (IPCC) (2014) refers to climate change as a change in the state of the climate that persists for an extended period, typically decades or longer. It refers to any change in climate over time, whether due to natural variability or as a result of human activity. Similarly, Onubuogu and Esiobu (2014) define climate change as variations in climate that are attributed indirectly or directly to human activities which alter the composition of the global atmosphere and which are in addition to natural variability observed over a comparable period of time. Thus, climate change describes a significant and sustained adjustment in the geometric distribution of the global climatic environment over time.

Climate change is seen to be associated with increased frequency and intensity of extreme weather conditions. Though the impacts of climate change could be said to be felt in every aspect of the Nigerian economy, the agricultural sector suffers more from this impact as a result of its high dependence on climate variables. Agricultural production in Nigeria is mostly practiced at a subsistence level characterised by high dependence on rain. Unfortunately, the

\footnotetext{
${ }^{1}$ Lecturer, Department of Agricultural Economics and Extension, University of Port Harcourt, Rivers State, Nigeria, Email: clara.ifeanyi-obi@uniport.edu.ng,ORCiD: 0000-0003-4816-6774
} 
climate has grossly changed, and as such, affects the lives of many people, especially the poor rural dwellers who depend mostly on agricultural activities for sustenance. Their livelihoods and food security, already endangered by some health and socio-economic problems, are even more endangered by the impacts of climate change (Akpodiogaga \& Odjugo, 2010; Odjugo, 2010). Therefore, adaptation to climate change has become an important issue.

The United Nations Development Programme (UNDP, 2012) stated that climate change impacts men and women differently, given their different roles and responsibilities at the household and community levels. It explains that women are more exposed and vulnerable to climate change because they are often poorer, receive less education, and are not involved in political and household decision-making processes that affect their lives. Thus, climate change aggravates already existing problems faced by women in developing countries whose livelihood depends on agriculture and access to natural resources. Similarly, the Food and Agriculture Organisation of the United Nations (FAO, 2011) stated that agriculture is underperforming in many developing countries for a number of reasons. Among these is the fact that women lack the resources and opportunities they need to make the most productive use of their time. FAO (2011) went further to explain that women are farmers, workers and entrepreneurs, but almost everywhere they face more severe constraints than men in accessing productive resources, markets and services. This "gender gap" hinders their productivity and reduces their contribution to the agricultural sector as well as the achievement of broader economic and social development goals. Closing the gender gap in agriculture would produce significant gains for society by increasing agricultural productivity, reducing poverty and hunger, and promoting economic growth.

Social exclusion is a breach of social bond and is seen as a process of decreased participation, access and solidarity (Silver, 2007). It also stresses social distance, marginalisation, and inadequate integration of a particular group or area in a society. Silver (2007) viewed social exclusion at two levels: at the societal level as inadequate social cohesion or integration, and at the individual level as the lack of opportunity to function in expected social activities and to build meaningful social relations. Women in Nigeria, despite their numerous contributions to food production and family upkeep, suffer social exclusion. They play a significant role in agricultural development in Nigeria, accounting for over $70 \%$ of the labour force, thus playing a pivotal role in sustaining the economy (Anyoha, 2011; Chandy, 2012; Idachaba, 1993; Meyer \& Sullivan, 2011; Olatunji, Ifeanyi-Obi \& Etuk, 2015). Rural women in Nigeria have generally borne and still bear the primary responsibility of their family survival, even with unequal access to production and development resources (Ogunlela \& Mukhtar, 2009; Ojutule \& Elizabeth, 2017; Okunade, 2007; Olawoye, 2007).

In rural areas where most of the world's hungry people live, women produce most of the food consumed locally. Their contribution could be much better if they had equal access to essential resources and services such as credit facilities and training. When women are excluded from basic agricultural inputs or resources in general, there will be a limit in the extent they can attain in food production, thereby reducing the level of farm output generated by women. Reduced food security and productivity could be as a result of the exclusion of women from land ownership (Ifeanyi-Obi, Olatunji \& Akpala, 2014; Obasi, 2005). The standard of living of many farm families depends on the income received by the women from the sales of the farm produce, and so the exclusion of women from access to natural resources will lead to a decreased standard of living for the farm families. Women are also excluded in the aspect of policy making in agriculture which has led to an increased ignorance of women on some basic 
policies in the agricultural sector as a whole. The involvement of women in the policy making process would boost the agricultural sector as their participation will enable them to identify and develop food security projects, and also help inform them of their right to some farming inputs, for example, seeds and fertilizers.

However, due to their generally weak position in society and family, women are not usually included in discussions and decision-making processes related to climate change or any other issue. Their limited access to information and resources such as land and credit further prevents them from developing their capacities in agriculture, even though they play a crucial role in food security. Females are often ignored, overlooked, and not taken seriously when they try to get involved or make their contributions and share their knowledge. In some cases, they are not regarded as proper farmers, but rather called farm wives, and as such, are not capable of producing and sharing valuable knowledge about farming. This poses a great challenge to them, particularly in developing their capacity for successful climate change adaptation.

Successful adaptation to climate change requires holistic efforts, unrestricted access to information and resources, and team effort. These will not be possible in an environment where indices of exclusion still thrive. Unfortunately, some of these indices of exclusion are covered up with some cultural practices making it difficult to explicitly deal with them. Nevertheless, knowledge on the deprivations and negative effects of exclusion will help poor rural dwellers to identify all forms of exclusion and overcome the associated challenges, particularly those posing a serious challenge to climate change adaptation.

It is against this background that this study assessed the effects of social exclusion on climate change adaptation of female arable crop farmers. The paper tests the hypothesis that socioeconomic characteristics of female arable crop farmers in Abia State do not significantly affect the level of social exclusion suffered. The specific objectives of this paper were to:

1. Describe the socio-economic characteristics of female arable crop farmers in Abia State.

2. Ascertain whether female arable crop farmers face social exclusion in the study area.

3. Identify the level of social exclusion suffered by female arable crop farmers in Abia State.

4. Assess the effects of social exclusion on female arable crop farmers to climate change adaption in the study area.

5. Determine the activities that could reduce social exclusion amongst female arable crop farmers in Abia State.

\section{METHODOLOGY}

\subsection{Study area}

The study was conducted in Abia State of Nigeria. Abia State is one of the 36 states in Nigeria and is located in the south-eastern agro-ecological zones of Nigeria. Abia State lies between latitudes $5^{\circ} 49^{\prime}$ and $6^{\circ} 12^{\prime}$ north of the equator, and longitudes $7^{\circ} 23^{\prime}$ and $8^{\circ} 02^{\prime}$ east of the Greenwich meridian. The climate is tropical and humid all year round. The rainy season ranges from March to October, while the dry seasons occur from November to February. The mean annual rainfall ranges from $2000 \mathrm{~mm}$ to $2500 \mathrm{~mm}$ with the southern areas receiving more than the northern areas. The temperature ranges from a minimum of $22^{\circ} \mathrm{C}$ to a maximum of $31^{\circ} \mathrm{C}$ 
(Okezie, Sulaiman \& Nwosu, 2012). The vegetation is predominantly a lowland forest. Abia State is divided into three agricultural zones: Aba, Umudike and Ohafia agricultural zones. The major occupation of the inhabitants is farming. The major crops grown are arable crops (e.g. yam, cassava, rice, maize, cocoyam, plantain, pepper, melon, etc.) and economic crops (e.g. oranges, oil palm, kola nut, cocoa, bush mango, oil bean seed, bread fruit, etc.). Crop farms are usually in small holdings of about 0.5 to 3 hectares (Ezeali, 2015).

\subsection{Study design and data collection}

The study involved female arable crop farmers in Abia State. A multi-stage sampling procedure was employed to select the sample for this study. The first stage comprised of random selection of one agricultural zone from the three zones in the state. Aba agricultural zone was selected. This zone comprised of 12 blocks. The second stage comprised of random selection of six blocks from the 12 blocks in the zone. The third stage was the random selection of two circles from each of the selected blocks, giving a total of 12 circles for the study. The final stage was the selection of 10 female arable crop farmers from each of the selected circles, giving a total of 120 respondents for the study.

Structured questionnaires were used for literate female arable crop farmers while interview schedules were employed for illiterate female arable crop farmers. The questionnaire was face and content validated to ensure it measured the construct of interest. The split-half method was used to assess the reliability of the research instrument. A total of 40 copies of the questionnaire was administered to 40 respondents who were randomly selected from two blocks not included in the study. Data collected were shared into two categories of even and odd numbers. These were correlated using Pearson Product Moment Correlation (PPMC), the result of the analysis yielded a correlation coefficient of 0.78 which, according to Udofia (2011), is reliable.

\subsection{Data analysis}

Data collected for this study were analysed using descriptive statistical tools and inferential statistics. The research objectives were analysed using the descriptive statistical tools while the hypothesis was tested using ordinary least square (OLS) multiple regression analysis. Level of social exclusion suffered by the female arable crop farmers was captured using a four-point Likert type scale rated as follows: Very high $=4$; high $=3$; low $=2$; very low $=1$. A midpoint of 2.5 was obtained, and based on this, mean scores greater than or equal to 2.5 imply that the exclusion suffered was high, while mean scores less than 2.5 imply low exclusion suffered. Effects of social exclusion on climate change adaptation of female arable crop farmers and activities to reduce social exclusion of female arable crop farmers were captured using a fourpoint Likert type scale rated as follows: Strongly agree $=4$; agree $=3$; disagree $=2$; strongly disagree $=1$. Again, a midpoint of 2.5 was obtained, and based on this, any mean score greater than or equal to 2.5 implies agreement with the statement, and any mean score less than 2.5 implies disagreement with the statement.

The OLS regression model is stated as follows: $\mathrm{Y}_{\mathrm{a}}=\mathrm{f}\left(\mathrm{X}_{1}, \mathrm{X}_{2}, \mathrm{X}_{3}, \mathrm{X}_{4}, \mathrm{X}_{5}, \mathrm{X}_{6}, \mathrm{X}_{7}, \mathrm{X}_{8}, \mathrm{X}_{9}, \mathrm{e}\right)$

Where $\mathrm{Y}_{\mathrm{a}}=$ Index of level of social exclusion suffered by female arable crop farmers (based on statements measured on four-point Likert type rating scale of Very High $=4$, High $=3$, low $=2$, very low $=1$ ). 
$\mathrm{X}_{1}=$ Age (measured in years)

$\mathrm{X}_{2}=$ Marital status (Dummy variable, single $=1$, married $=2$ )

$\mathrm{X}_{3}=$ Educational status (Number of years spent in school)

$\mathrm{X}_{4}=$ Farming experience (Measured in years)

$\mathrm{X}_{5}=$ Household size (Number of persons per household)

$\mathrm{X}_{6}=$ Major occupation (Dummy variable, farming $=1$, non-farming $=2$ )

$\mathrm{X}_{7}=$ Farm size (measured in plot)

$\mathrm{X}_{8}=$ Monthly income (measured in Naira)

X9 $=$ Major aim of production (measured on a three-point Likert type scale of sale $=1$, consumption $=2$, both $=3$ )

$\mathrm{e}=$ error term

It is expected a priori that the coefficients of $\mathrm{X}_{1}, \mathrm{X}_{2}, \mathrm{X}_{3}, \mathrm{X}_{4}, \mathrm{X}_{5}, \mathrm{X}_{6}, \mathrm{X}_{7}, \mathrm{X}_{8}$, and $\mathrm{X}_{9}>0$.

Four functional forms of the model, namely linear, double log, exponential, and semi-log were estimated. The linear equation was chosen based on the appropriateness of signs, magnitude of coefficient of multiple determinations $\left(\mathrm{R}^{2}\right)$, statistical significance of the variables, and a priori theoretical expectations. The relationship between the dependent variable and each of the independent variables was examined using the four functional forms: linear, semi-log, exponential, and double log.

Linear: $\mathrm{Y}=\mathrm{B}_{0}+\mathrm{B}_{1} \mathrm{X}_{1}+\mathrm{B}_{2} \mathrm{X}_{2}+\mathrm{B}_{3} \mathrm{X}_{3}+\mathrm{B}_{4} \mathrm{X}_{4}+\mathrm{B}_{5} \mathrm{X}_{5}+\mathrm{B}_{6} \mathrm{X}_{6}+\mathrm{B}_{7} \mathrm{X}_{7}+\mathrm{B}_{8} \mathrm{X}_{8}+\mathrm{B} 9 \mathrm{X}_{9}$

$+\mathrm{e}$

Semi-Log: $\mathrm{Y}=\mathrm{B} 0+\mathrm{B}_{1} \log \mathrm{X}_{1}+\mathrm{B}_{2} \log \mathrm{X}_{2}+\mathrm{B}_{3} \log \mathrm{X}_{3}+\mathrm{B}_{4} \operatorname{Iog} \mathrm{X}_{4}+\mathrm{B}_{5} \log \mathrm{X}_{5}+\mathrm{B}_{6} \log \mathrm{X}_{6}+$ $\mathrm{B} 7 \log \mathrm{X}_{7}+\mathrm{B} 8 \log \mathrm{X}_{8}+\mathrm{B} 9 \log \mathrm{X} 9+\mathrm{e}$

Exponential: $\log \mathrm{Y}=\mathrm{B}_{0}+\mathrm{B}_{1} \mathrm{X}_{1}+\mathrm{B}_{2} \mathrm{X}_{2}+\mathrm{B}_{3} \mathrm{X}_{3}+\mathrm{B}_{4} \mathrm{X}_{4}+\mathrm{B}_{5} \mathrm{X}_{5}+\mathrm{B}_{6} \mathrm{X}_{6}+\mathrm{B}_{7} \mathrm{X}_{7}+\mathrm{B}_{8} \mathrm{X}_{8}+$ $\mathrm{B}_{8} \mathrm{X}_{8+} \mathrm{e}$

Double Log: $\log \mathrm{Y}_{=} \mathrm{B}_{0}+\mathrm{B}_{1} \log \mathrm{X}_{1}+\mathrm{B}_{2} \log \mathrm{X}_{2}+\mathrm{B}_{3} \log \mathrm{X}_{3}+\mathrm{B}_{4} \log \mathrm{X}_{4}+\mathrm{B}_{5} \log \mathrm{X}_{5}+\mathrm{B}_{6} \log \mathrm{X}_{6}$ $+\mathrm{B} 7 \log \mathrm{X}_{7}+\mathrm{B} 8 \log \mathrm{X}_{8}+\mathrm{B} 8 \log \mathrm{X}_{8}+\mathrm{e}$

$\mathrm{B}_{\mathrm{O}}=$ intercept

$\mathrm{B}_{1}, \mathrm{~B}_{2} \ldots \mathrm{B} 8=$ estimated coefficients

$\mathrm{e}=$ error term

\section{RESULTS AND DISCUSSION}

\subsection{Socio-economic characteristics of female arable crop farmers}

From Table 1, it can be seen that $81 \%$ of the respondents were married with a mean age of 46 years, indicating that the respondents are old enough to have experienced the change in climate, and hence are able to provide reasonable answers to the research questions. Approximately $45 \%$ of the women attended tertiary institutions. This could be due to the fact that the study was conducted in a semi-urban area, hence the high number of literate women. Farming $(65 \%)$ is the major occupation of the female arable crop farmers with an average farming experience and monthly income of 19 years and N33 581 respectively. The large majority (93\%) of the female arable crop farmers have farm sizes of less than 1ha of land with both mono-cropping and mixed cropping (71\%) being practiced. 
S. Afr. J. Agric. Ext.

Vol. 48 No. 1, 2020: 55 - 69

http://dx.doi.org/10.17159/2413-3221/2020/v48n1a526
Ifeanyi-obi \& Ugorji

(License: CC BY 4.0)

Table 1: Socio-economic characteristics of female arable crop farmers

\begin{tabular}{|c|c|c|c|}
\hline VARIABLE & FREQUENCY & PERCENTAGE (\%) & MEAN \\
\hline \multicolumn{4}{|l|}{ Age } \\
\hline$\leq 25$ & 6 & 5.20 & 46 \\
\hline $26-35$ & 22 & 19.00 & \\
\hline $36-45$ & 39 & 33.30 & \\
\hline $46-55$ & 26 & 22.40 & \\
\hline $56-65$ & 16 & 13.10 & \\
\hline $66-75$ & 8 & 7.00 & \\
\hline \multicolumn{4}{|l|}{ Marital status } \\
\hline Single & 22 & 18.80 & \\
\hline Married & 95 & 81.20 & \\
\hline \multicolumn{4}{|l|}{ Educational status } \\
\hline Primary & 21 & 17.00 & \\
\hline Secondary & 44 & 37.70 & \\
\hline Tertiary & 52 & 45.30 & \\
\hline \multicolumn{4}{|c|}{ Farming experience (in years) } \\
\hline $1-10$ & 44 & 38.70 & 18.57 \\
\hline $11-20$ & 34 & 23.80 & \\
\hline $21-30$ & 16 & 15.60 & \\
\hline $31-40$ & 17 & 16.70 & \\
\hline $41-50$ & 6 & 5.20 & \\
\hline \multicolumn{4}{|l|}{ Household size } \\
\hline $1-4$ & 34 & 29.00 & 5.50 \\
\hline $5-8$ & 77 & 65.80 & \\
\hline $9-12$ & 6 & 5.20 & \\
\hline \multicolumn{4}{|l|}{ Major occupation } \\
\hline Farming & 77 & 65.8 & \\
\hline Non-farming & 40 & 34.20 & \\
\hline \multicolumn{4}{|c|}{ Monthly income (in Naira) } \\
\hline$\leq 20000$ & 73 & 61.40 & 33581.20 \\
\hline $21000-60000$ & 28 & 23.00 & \\
\hline $61000-100000$ & 11 & 9.50 & \\
\hline $101000-140000$ & 3 & 2.60 & \\
\hline $141000-180000$ & 1 & 0.90 & \\
\hline $181000-220000$ & 1 & 0.90 & \\
\hline $221000-260000$ & 0 & 0 & \\
\hline $261000-300000$ & 2 & 1.70 & \\
\hline \multicolumn{4}{|c|}{ Size of plot (in hectares) } \\
\hline$\leq 1$ & 109 & 93.20 & \\
\hline $1-2$ & 6 & 5.20 & \\
\hline$\geq 3$ & 2 & 1.70 & \\
\hline \multicolumn{4}{|c|}{ Cropping system practiced } \\
\hline Mono-cropping & 2 & 1.70 & \\
\hline Mixed cropping & 30 & 26.60 & \\
\hline Both & 83 & 71.70 & \\
\hline
\end{tabular}




\begin{tabular}{|l|c|c|c|}
\hline Major aim of production & & & \\
\hline Consumption & 6 & 5.10 & 2.83 \\
\hline Sales & 8 & 6.80 & \\
\hline Both & 103 & 88.1 & \\
\hline
\end{tabular}

Source: Computed from Field Survey, 2018

\subsection{Social exclusion amongst female arable crop farmers in the study area}

From Table 2, it can be seen that there is social exclusion amongst female arable crop farmers in Abia State. Of the 10 statements used to capture social exclusion in the study area, the respondents indicated that they suffer exclusion in all the aspects with unequal access to credit facilities (84\%), denial of access to land ownership (83\%), limited access to available resources (81\%), denial to head groups and associations (77\%), and unequal access to social services (76\%) as the major areas of social exclusion suffered. The Department for International Development (DFID, 2005) noted that women are often socially excluded. This could sometimes be deliberate through laws and policies that deny them access to certain resources, even inheritance. In some tribes, social exclusion could be as a result of some traditional beliefs and practices that undermine women and irrationally subject them to the authority of their husbands. In some cases, people unofficially perpetuate social exclusion through undue discrimination against women in society.

Table 2: Social exclusion amongst female arable crop farmers in Abia State

\begin{tabular}{|l|c|}
\hline Variable & Percentage \\
\hline Lack of access to information sources. & $70^{*}$ \\
\hline Lack of access to available resources (e.g. farm inputs). & $81^{*}$ \\
\hline Denial of access to land ownership. & $83^{*}$ \\
\hline Unequal access to social services (e.g. education). & $76^{*}$ \\
\hline Denial of freedom to exercise their voice. & $68^{*}$ \\
\hline Denial of involvement in decision making process is limited. & $69^{*}$ \\
\hline Unequal access to credit facilities (e.g. loans, insurances, grants). & $84^{*}$ \\
\hline $\begin{array}{l}\text { Denial of opportunity to participate in social activities that will improve our } \\
\text { livelihood. }\end{array}$ & $72^{*}$ \\
\hline Denial to head groups and organisations. & $77^{*}$ \\
\hline Geographic segregation. & $73^{*}$ \\
\hline
\end{tabular}

*Multiple responses

Source: Field survey, 2018

\subsection{Level of social exclusion suffered by female arable crop farmers in the study area}

Table 3 displays the mean scores for the statements used to capture the level of social exclusion suffered by these female arable crop farmers, and it shows that a high level of social exclusion is experienced in accessing credit facilities $(\overline{\mathrm{x}}=3.1)$, access to available resources $(\overline{\mathrm{x}}=2.9)$, ownership of land $(x=2.9)$, access to social services $(\bar{x}=2.7)$, and headships of social groups 
and organisations ( $\bar{x}=2.7)$. FAO (2011) stated that agriculture is an important engine of growth and poverty reduction, but the sector is underperforming in many countries, particularly in subSaharan Africa because women, who are often a crucial resource in agriculture and the rural economy, face constraints that reduce their productivity. It noted that women's participation in rural labour markets varies considerably across regions, but invariably women are overrepresented in unpaid, seasonal and part-time work, and the available evidence suggests that women are often paid less than men for the same work (FAO, 2011). Similarly, FAO and Economic Community of West African States (ECOWAS), country gender assessment series (FAO, 2018), noted that despite women's increasing contribution to livestock and crop production in Nigeria, they still suffer deprivations and exclusion in some important areas such as land ownership, holding of positions in mixed farmers associations, wages received in income generating activities, as well as a right to their own savings and financial assets. The results of this study confirms that women still suffer a high level of exclusion in many aspects of livelihood.

Table 3: Level of social exclusion faced by the respondents

\begin{tabular}{|l|c|}
\hline VARIABLE & MEAN \\
\hline Lack of access to agricultural information. & $2.2^{*}$ \\
\hline Lack of access to available resources (e.g. farm inputs). & $2.9^{* *}$ \\
\hline Denial of access to land ownership. & $2.9^{* *}$ \\
\hline Unequal access to social services (e.g. education). & $2.7^{* *}$ \\
\hline Denial of freedom to exercise their voice. & $2.5^{* *}$ \\
\hline Denial of involvement in decision making process is limited. & $2.5^{* *}$ \\
\hline Unequal access to credit facilities (e.g. loans, insurances, grants). & $3.1^{* *}$ \\
\hline $\begin{array}{l}\text { Denial of opportunity to participate in social activities that will improve our } \\
\text { livelihood. }\end{array}$ & $2.5^{* *}$ \\
\hline Denial to head groups and organisations. & $2.7^{* *}$ \\
\hline Geographic segregation. & $2.6^{* *}$ \\
\hline
\end{tabular}

$*$ Mean $\leq 2.5$ low level

$* *$ Mean $\geq 2.5$ high level

Source: Field Survey, 2018

\subsection{Effects of social exclusion on female arable crop farmers' adaptation to climate change}

The results from Table 4 show that poor access to credit facilities that could improve the buying of farm inputs for better climate change adaptation $(\bar{x}=2.8)$, inadequate access to important agricultural equipment that could enhance climate change adaptation effort $(\bar{x}=2.7)$, lack of ownership of farm land for increased farm $\operatorname{size}(\bar{x}=2.8)$, limitation of participation in decision making process of some important climate change adaptation activities $(\bar{x}=2.6)$, and reduction of access to farm inputs for better adaptation $(\bar{x}=2.7)$ are the significant effects of social exclusion on female arable crop farmers' adaptation to climate change. Climate change adaptation amongst farmers is known to be affected by various factors ranging from socio- 
economic to cultural factors. This includes access to information and available resources, ownership of land, membership of farmer groups, access to improved farm inputs, educational status, age, and income level (Apata, Samuel \& Adeola, 2009; Dang et al, 2019; Ifeanyi-Obi et al, 2017; Ifeanyi-Obi, Asiabaka \& Adesope, 2014; Onubuogu \& Esiobu, 2014).

Respondents who were interviewed disclosed that they spent large sums of money on leasing land for agricultural activities, making it difficult for them to expand their farm size as a means of climate change adaptation. Furthermore, it was noted that their male counterparts have access to large expanses of land inherited from their fathers and can expand their farm size reasonably without having to spend as much money as they do. In addition, a lack of access to relevant information on available trainings, farm inputs, and extension services make it more difficult for them to adapt to climate change as these are important variables needed for effective climate change adaptation. They noted that in most cases, they are denied holdings of important positions in associations with mixed membership, even when the female candidate is known to possess a better capacity to handle the position. This demoralises them and makes adaptation efforts less effective. 
Table 4: Effects of social exclusion on climate change adaptation of female arable crop

\begin{tabular}{|l|c|}
\hline VARIABLE & MEAN \\
\hline $\begin{array}{l}\text { Social exclusion results to inadequate access to basic climate change adaptation } \\
\text { information. }\end{array}$ & $2.4^{*}$ \\
\hline $\begin{array}{l}\text { It causes poor access to credit facilities that could help me buy improved farm } \\
\text { inputs for better climate change adaptation. }\end{array}$ & $2.8^{* *}$ \\
\hline $\begin{array}{l}\text { Inadequate access to important agricultural equipment that could enhance my } \\
\text { climate change adaptation effort. }\end{array}$ & $2.7^{* *}$ \\
\hline I lack ownership of farmland for increased farm size. & $2.8^{* *}$ \\
\hline $\begin{array}{l}\text { It limits my participation in decision making process of some important climate } \\
\text { change adaptation activities. }\end{array}$ & $2.6^{* *}$ \\
\hline It reduces my access to farm inputs for better adaptation, e.g. seedlings. & $2.7^{* *}$ \\
\hline $\begin{array}{l}\text { It limits my access to adequate agricultural extension services that could improve } \\
\text { my climate change adaptation activities. }\end{array}$ & $2.5^{* *}$ \\
\hline $\begin{array}{l}\text { It denies me access to membership in cooperative society that could enhance my } \\
\text { climate change adaptation effort. }\end{array}$ & $2.4^{* *}$ \\
\hline Social exclusion leads to reduced agricultural productivity. & $2.7^{* *}$ \\
\hline Social exclusion generally militates against my climate change adaptation effort. & $2.5^{* *}$ \\
\hline Social exclusion discourages me from investing in agriculture. & $2.5^{* *}$ \\
\hline It leads to inability to adopt to climate change mitigation strategies. & $2.6^{* *}$ \\
\hline
\end{tabular}

\section{farmers}

$*$ Mean $\leq 2.5$ implies disagree

$* *$ Mean $\geq 2.5$ implies agree

Source: Field Survey, 2018

\subsection{Activities to reduce social exclusion amongst female arable crop farmers in the study}

Table 5 portrays the activities that could reduce social exclusion amongst female arable crop farmers in the study area. Formal education of women $(\bar{x}=2.2)$, sensitisation workshops to educate rural people on the negative effects of social exclusion $(\bar{x}=2.3)$, skill acquisition and empowerment programmes for women $(\bar{x}=2.4)$, involvement in cooperative societies $(\bar{x}=$ 2.2 ), enlightenment by extension and advisory services on the implications of social exclusion $(\bar{x}=2.2)$, and non-formal educational programmes for rural women $(\bar{x}=2.3)$ were highlighted as the major activities that could reduce social exclusion in the study area. Findings show that the farmers consented that all the suggested ways of reducing social exclusion are significant. This result agrees with recommendations made by FAO and ECOWAS, country gender assessment series (FAO, 2018), on how to promote gender in agriculture and rural development in Nigeria, which includes increased representation of women in leadership positions, women's rights to ownership, savings and decision making on their agricultural investments and revenues, ban or impose strict penalties on negative traditional and cultural practices that are obstacles to the national and individual development of women, gender responsive budgeting, 
increased enlightenment of the citizenry on women rights and privileges, increased funding for women education, as well as programmes and policies that will improve women ownership of land (FAO, 2018). Similarly, Odurukwe, Matthews-Njoku and Ejiogu-Okereke (2006) noted that women's increased access to resources can contribute in enhancing their livelihood activities.

Table 3: Activities that could reduce social exclusion of female arable crop farmers

\begin{tabular}{|l|c|}
\hline VARIABLE & MEAN \\
\hline Formal education of women. & $2.2^{* *}$ \\
\hline $\begin{array}{l}\text { Sensitisation workshops to educate rural people on the negative effects of social } \\
\text { exclusion. }\end{array}$ & $2.3^{* *}$ \\
\hline Skill acquisition and empowerment programmes for women. & $2.4^{* *}$ \\
\hline Involvement in cooperative societies. & $2.2^{* *}$ \\
\hline $\begin{array}{l}\text { Enlightenment by extension and advisory services on the implications of social } \\
\text { exclusion. }\end{array}$ & $2.2^{* *}$ \\
\hline Non-formal educational programmes for rural women. & $2.3^{* *}$ \\
\hline
\end{tabular}

$*$ Mean $\leq 2$ implies disagree

$* *$ Mean $\geq 2$ implies agree

Source: Field Survey, 2018

\subsection{Test of hypothesis}

$\mathrm{H}_{0}$ : the socio-economic characteristics of female arable crop farmers in Abia State do not significantly affect the level of social exclusion suffered.

$\mathrm{H}_{\mathrm{A}}$ : the socio-economic characteristics of female arable crop farmers in Abia state significantly affect the level of social exclusion suffered.

Ordinary least square regression analysis was used to determine the relationship between the level of social exclusion suffered by female arable crop farmers and their socio-economic characteristics. Based on the appropriateness of signs, number of significant variables, and the magnitude of $\mathrm{R}^{2}$, the linear function was chosen as the lead equation. This result was confirmed by the F-value of 10.913 which was significant at both 0.05 and 0.01 probability level and further confirmed by an overall p-value of 0.000 . Therefore, the null hypothesis, which states that the socio-economic characteristics of female arable crop farmers in Abia State do not significantly affect the level of social exclusion suffered, was rejected.

The results in Table 6 reveal that $69.7 \%\left(\mathrm{R}^{2}=.697\right)$ of variation in the level of social exclusion suffered by female arable crop famers could be explained by their socio-economic characteristics. The result indicated that four out of the eight independent variables correlated significantly with the level of social exclusion suffered by the female arable crop farmers.

Age was found to correlate negatively and significantly with the level of social exclusion suffered by the female arable crop farmers. This could imply that female arable crop farmers in the study area who are advanced in age feel less of the effects of social exclusion than their 
younger counterparts. This could be as a result of their experience over the years on how to manage and cope with social exclusion.

The result further revealed that the educational status correlated negatively and significantly with the level of social exclusion suffered. This implies an inverse relationship; the higher the educational status, the lower the level of social exclusion suffered. This could be explained by the fact that farmers who are more educated tend to suffer less social exclusion than the less educated. This could be as a result of their education which exposes them to their rights and privileges as well as enhances their capacity to manage any form of exclusion. In addition, it is observed that women who are educated are more revered and respected by their male counterparts in society.

Table 4 Regression results showing the relationship between the socio-economic characteristics of female arable crop farmers and the level of social exclusion suffered

\begin{tabular}{|l|c|c|c|c|}
\hline & Linear & Semi log & Double log & $\begin{array}{c}\text { Exponential } \\
\text { model }\end{array}$ \\
\hline Constant & 69.98 & 3.99 & 4.97 & 68.10 \\
\hline Educational status & $(10.78) * *$ & $(56.9) * *$ & $(25.13) * *$ & $(5.51) * *$ \\
\hline Age & -7.91 & -0.066 & 0.074 & 8.13 \\
\hline & $-4.22) * *$ & $(4.16) * *$ & $(-3.34) * *$ & $(-2.54) * *$ \\
\hline Household size & $(-2.58) *$ & $(2.56) *$ & -0.006 & 5.234 \\
\hline & 0.35 & 0.06 & 0.021 & $(1.878)$ \\
\hline Aim of production & $(0.45)$ & $(0.51)$ & $(0.43)$ & $(0.682)$ \\
\hline & 0.25 & 0.0013 & 0.234 & 2.25 \\
\hline Farm size & $(0.19)$ & $(1.14)$ & $(1.213)$ & $(1.387)$ \\
\hline & 0.63 & $1.09 \mathrm{E}-06$ & 0.0379 & 3.65 \\
\hline Income & $(-4.58) * *$ & $(-4.25) * *$ & $(-3.42) * *$ & $(-0.0009) * *$ \\
\hline & 0.29 & 0.003 & 0.053 & -4.102 \\
\hline $\begin{array}{l}\text { Farming } \\
\text { experience }\end{array}$ & $(-3.04) *$ & $(-1.56)$ & $(-2.10) *$ & $(-1.402) *$ \\
\hline & 0.23 & 0.033 & 0.037 & 0.256 \\
\hline Major occupation & $(0.17)$ & $(0.28)$ & $(0.187)$ & $(0.762)$ \\
\hline & $(0.62$ & 0.0027 & 0.0185 & 2.340 \\
\hline $\mathbf{R}^{\mathbf{2}}$ & $\mathbf{0 . 6 9 7}$ & $(0.194)$ & $(0.581)$ & $(0.253)$ \\
\hline $\begin{array}{l}\text { F-statistic (F- } \\
\text { value) }\end{array}$ & $\mathbf{1 0 . 9 1 3}$ & $\mathbf{0 . 5 3 4}$ & $\mathbf{0 . 4 7 6}$ & $\mathbf{0 . 4 8 7}$ \\
\hline Pro (f-stat) & $\mathbf{0 . 0 0 0 0}$ & $\mathbf{9 . 6 6 3}$ & $\mathbf{7 . 1 5 1}$ & $\mathbf{7 . 4 8 2}$ \\
\hline
\end{tabular}

Figures in the first row are regression coefficients

t-ratios are in parentheses

*t-ratios significant at 0.05 probability level

$* *$ t-ratios significant at 0.01 probability level

Source: Computed from survey data, 2018 
Furthermore, farm size and monthly income were shown to correlate negatively and significantly with the level of social exclusion suffered. This implies that as farm size and monthly income increases, the social exclusion suffered increases. A large farm size could suggest a higher income which could empower the female farmers to be more exposed, hence reduced intimidation and exclusion suffered.

\section{CONCLUSION AND RECOMMENDATIONS}

The study concludes that female arable crop farmers suffer social exclusion with denial of access to available resources, land and credit facilities as the major areas of exclusion. This also affects their capacity to adapt to climate change as access to some facilities that will enhance their adaptive capacity is denied. Socio-economic characteristics were found to correlate with the level of social exclusion suffered, implying that enhancement of these variables could positively enhance the capacity of these female arable crop farmers to mitigate social exclusion.

It was therefore recommended that formal education of women, sensitisation workshops to educate rural people on the negative effects of social exclusion, skill acquisition and empowerment programmes for women, involvement in cooperative societies' membership, enlightenment by extension and advisory services on the implications of social exclusion, and non-formal educational programmes for rural women could be effective in the reduction of social exclusion amongst female arable crop farmers.

\section{REFERENCES}

AKPODIOGAGA, P. \& ODJUGO, P.A.O., 2010. General overview of climate change impacts in Nigeria. J. Hum. Ecol., 29(1):47-55.

ANYOHA, N.O., 2011. Factors influencing rural women's participation in development programmes in Rivers State Nigeria: Key for social exclusion elimination. Mobilization, 6(1):31-6.

APATA, T.G., SAMUEL, K.D. \& ADEOLA, A.O., 2009. Analysis of climate change perception and adaptation among arable food crop farmers in South Western Nigeria. Paper presented to The Conference of International Association of Agricultural Economics. Beijing, China.

CHANDY, P., 2012. The role of women in agriculture. Available from: http://www.Ica.Coop/en/events-60 on 6/1/2012

DANG, H.L., LI, E., NUBERG, I. \& BRUWER, J., 2019. Factors influencing the adaptation of farmers in response to climate change: A review. Clim. Dev., 11(9):765-774.

DEPARTMENT FOR INTERNATIONAL DEVELOPMENT (DFID), 2005. Social exclusion review. Available from: https://www.odi.org/sites/odi.org.uk/files/odiassets/publications-opinion-files/2301.pdf.

EZEALI, C.B.O., 2015. Influence of gender on sustainable management of forest resources in Abia State, Nigeria. PhD Thesis, University of Nigeria.

FOOD AND AGRICULTURE ORGANISATION OF THE UNITED NATIONS (FAO), 2011. The role of women in agriculture. ESA Working Paper No. 11-02. FAO, Italy. 
FOOD AND AGRICULTURE ORGANISATION (FAO), 2018. National gender profile of agriculture and rural livelihoods - Nigeria. Rome, Italy.

IDACHABA, F.S., 1993. Agricultural and rural development under the Babangida administration. In Seven Years of IBB: The Economy (pp.84-188). Lagos: Daily Times.

IFEANYI-OBI, C.C., ASIABAKA, C.C. \& ADESOPE, O.M., 2014. Determinants of climate change adaptation measures used by crop and livestock farmers in Southeast Nigeria. Int. J. Humant. Soc. Sci., 19(9):61-70.

IFEANYI-OBI, C.C., OLATUNJI, S.O. \& AKPALA, J., 2014. Effects of social exclusion on agriculture activities of rural women in Ahoada Agricultural Zone of Rivers State. $J$. Environ. Sci. Toxicol. Food Technol., 8(9):5-10.

IFEANYI-OBI, C.C., TOGUN, A.O., LAMBOLL, R. \& AROKOYU, S., 2017. Socioeconomic determinants of cocoyam farmer's strategies for climate change adaptation in Southeast Nigeria. J. Agric. Ext., 21(2):91-104.

IPCC 2014. Climate change 2014: synthesis report. Contribution of working groups I, II and III to the fifth assessment report of the intergovernmental panel on climate change. [Core Writing Team, Pachauri RK, Meyer LA (eds)]. IPCC, Geneva, pp 151

MEYER, B.D. \& SULLIVAN, J., 2011. Further results on measuring the well-being of the poor using income and consumption. Can. J. Econ., 44(1):52-87.

OBASI, O.O., 2005. Women in rural development: The Nigerian experience. In Agricultural extension and rural sociology (pp.45-49). Enugu: Snaap Publishers.

ODJUGO, P.A.O., 2010. Regional evidence of climate change in Nigeria. J. Geogr. Reg. Plann., 3(6):142-150.

ODURUKWE, S., MATTHEWS-NJOKU, E.C. \& EJIOGU-OKEREKE, O.N., 2006. Impacts of the women in agriculture programme on women's lives: Implications for subsistence agricultural production of women in Imo State. Livestock Res. Rural Dev., 18(18):47-61.

OGUNLELA, Y.I. \& MUKHTAR, A.A., 2009. Gender issues in agriculture and rural development in Nigeria: The role of women. Human. Soc. Sci., 4(1):19-30.

OJUTULE, A.M. \& ELIZABTH, A., 2017. Rural women's involvement in agriculture in Okpo District, Kogi State, Nigeria. Available from: https://globaljournals.org/GJSFR_Volume17/4-Rural-Womens-Involvement.pdf

OKEZIE, C.A., SULAIMAN, J. \& NWOSU, A.C. 2012. Farm-level determinants of Agricultural Commercialisation. International Journal of Agriculture and Forestry (IJAF), 2(2): 1-5. doi: 10.5923/j.ijaf.20120202.01

OKUNADE, E.O., 2007. Accessibility of agricultural credit and inputs to women farmers of Isoya rural development project. Res. J. Agric. \& Biol. Sci., 3(3):138-142.

OLATUNJI, S.O., IFEANYI-OBI, C.C. \& ETUK, U.R., 2015. Extension coverage of female crop farmers in Ogba/Egbema/Ndoni local government area of Rivers State. Int. J. Appl. Agric. Sci., 10(1):7-16.

OLAWOYE, J.E., 2007. Difficulties of rural women in securing resources for agricultural production. Ibadan: University of Ibadan. 
ONUBUOGU, G.C. \& ESIOBU, N.S., 2014. Trends, perceptions and adaptation options of arable crop farmers to climate change in Imo State, Nigeria: A logit multinomial model approach. World J. Agric. Sci., 2(5):108-122.

SILVER, H., 2007. Social exclusion. Available from: https://www.meyi.org/uploads/3/2/0/1/32012989/silver_-_social_exclusioncomparative_analysis_of_europe_and_middle_east_youth.pdf

UDOFIA, E.P., 2011. Applied statistics with multivariate methods. Enugu: Immaculate Publications Limited.

UNITED NATION DEVELOPMENT PROGRAMME (UNDP), 2012. Women's representation in leadership in Vietnam. Available from: https://www.undp.org/content/dam/vietnam/docs/Publications/31204_Women_s_Repre sentation_in_Leadership_in_Viet_Nam.pdf 
